\title{
MR. JUSTICE CARDOZO AND THE LAW OF TORTS
}

$\mathrm{HE}$ effect of Cardozo upon the progress of the law cannot be
judged merely by looking to his writings. As all who knew him are aware, the man was even greater than the judge. His passion for justice and his fear lest act or work of his should deprive anyone of that to which he was entitled appeared in his voice and words, as his love for humanity was apparent in his face. I suspect that Cardozo's greatest contribution was, as was that of James Barr Ames, the instilling into those with whom he came into personal contact a small part of the spirit which animated him. Each in his separate sphere was an apostle of the spirit of justice which lies at the roots of the common law and which is greater than the law itself. No one could long be with Cardozo without realizing that with the simplicity, modesty and gentleness of his character there was a driving spirit seeking to right the wrongs of the world. But his effect upon the law by direct personal contact is beyond my powers of appraisal. I knew him only as one of many whom he brushed in passing, leaving a sense of a great presence. In the attempt to appraise what he did for the law of torts, I shall speak only on the record made by his opinions in decided cases. First a few generalizations.

Cardozo was a progressive judge but not primarily a reforming judge. He did not remake the law of torts. On the contrary, by and large, he accepted the common law as he found it, merely choosing between precedents where choice was possible, and choosing the best. His power lay in his ability to see the plan and pattern underlying the law and to make clear the paths which had been obscured by the undergrowth of illogical reasoning. Perhaps because he realized the power of the court to make law, he was cautious in using this power, or perhaps his reluctance was due to the great intellectual modesty which was as obvious as it was real. It is true, however, that in all but a few of the tort cases in which he participated, his function was chiefly to 
clarify principles and not to create new interests. He was a critical but nevertheless a fond lover of the common law, realizing that it was not perfect but with faith that with gentle pressure it would respond adequately to the needs of those whom it served. In the few instances in which he went beyond the clear line of well-defined authority, he took but short steps, careful to preserve the principle that change should be gradual. At times, fearful of the consequences of an untried rule, he was unwilling to depart from precedent in extending liability where this might well have been done or where consistency to principle seemed to require it.

His entire record indicates that he did not first decide from some internal and unexplainable sense of justice that one of the parties was entitled to the decision and then find or invent a formula to fit the facts. Instead, he used principles deduced from the cases and weighed competing interests as had the judges who had gone before him. Nor did he allow his private opinions of policy to sway him from the lines into which the law had been moulded. He did his full part in causing the court to be a court of justice, but it was not by destroying it as a court of law. Personally solicitous for the poor and the maimed, and in criminal cases eager to find the scintilla of doubt which would keep from punishment one accused of crime, he did not become the protector of the injured merely because the defendant had ample funds to meet a judgment or had an ability to spread the loss. His scales were those of legal justice, not sentimental justice. As is true of most judges sitting on appellate courts, he was frequently called upon to perform the unwelcome task of denying compensation to persons who had been hurt and for whom he must have had great sympathy, but in whose favor a judgment contrary to existing rules had been rendered in a lower court by mistake or prejudice. In fact, in a majority of the tort cases in which he rendered opinions, the court denied the plaintiff recovery and, in most of the cases, deprived him of the judgment which had been awarded to him in a lower court.

I have no.doubt that Cardozo was the most important single influence in the development of torts in recent years. It is not 
chance that he was at his best in this field which touches most closely the everyday life of the community. Impatient of purely legalistic reasoning, interested primarily in people rather than in the intricacies of business, he found in torts perhaps the best field for the expression of his philosophy of life. With his power of understanding principles behind the rules and of expressing them in striking and unforgettable terms, he has become as truly a teacher of the lawyers of the future as are the instructors in the schools. Disregarding the occasional over-ornate method of expression, which at least did not lead to misunderstanding as did some of Holmes' cryptic statements, his opinions are models for courts and students alike. No school can afford to do without them in the instruction of students and no court can disregard them in dealing with matters upon which he has spoken. Principles, distorted by judicial errors or clouded by the over-use of fictions, are made manifest. Because he is picturing human problems and not merely manipulating legal formulae, the reading of his opinions is an intellectual adventure. Seldom does he evade logical difficulties; his work has a nicety of balance which by and large compels conviction, both to the professors whose tendency is to seek new rules and to create new interests and to the practicing lawyers who ordinarily dislike both new wine and old wine served in new bottles. In my own case, a re-reading of all the tort cases in which Cardozo rendered opinions leaves me with doubts as to the decisions of only two of them and in those two I am very likely wrong. I shall speak of them later.

\section{NEGLIGENCE}

Cardozo's greatest contribution to the law of torts was in the field of negligence, the principles of which are as simple as their application is difficult. To understand what he did in this branch of the law, it may be desirable to summarize its condition in I9I4 when he came to the bench.

The generalizations had already been made. It was no longer a patchwork built upon the ancient doctrine of trespass. The courts were tending to accept the famous statement of Brett, 
M. R., in Heaven v. Pender, " that actionable negligence consists of the neglect of the use of ordinary care or skill towards a person to whom the defendant owes a duty of observing ordinary care or skill, by which neglect the plaintiff without contributory negligence on his part, has suffered injury to his person or property." 1 The objective theory of negligence had been adopted and the "reasonably prudent man" had been invented. By and large both in England and the United States there was recognition of the policy of making a negligent person liable for harm resulting from his activities and of not imposing liability for unintended physical results where neither he nor someone acting for him had fallen below the standard of careful conduct. Fletcher $v$. $R y l a n d s,{ }^{2}$ with its tendency towards the creation of liability irrespective of negligence, had gained little headway in the United States. The doctrine of contributory negligence with its confusing "last clear chance" modification had become definitely established. But there were some anomalies and a great deal of uncertainty as to the limits of liability for negligent conduct.

There was and is the unsolved difficulty resulting from the common-law viewpoint that one is liable only if he harms another and is not liable in failing to confer a benefit upon another, the difficulty of distinction being accentuated by a series of cases distinguishing between " nonfeasance" and "misfeasance." This becomes crucial in cases which involve the undertaking of an obligation by the defendant as a contracting party or as a servant, and a failure by him to perform where the failure results in harm to third persons. It is in this field that we find the frequent use of the word "privity," which is a useful word in some portions of the law but not in the law of torts. Secondly, there was the profound confusion centering upon situations in which the courts found it necessary to use the language of legal causation, that is, situations in which the defendant had been guilty of fault and the problem was as to the limits of his liability. All were agreed that even the most faulty person was not responsible for all the consequences of his conduct, but although decisions could be fairly well harmonized, there was no general agreement as to the

1 II Q. B. D. 503 (1883).

23 COL.
2 L. R. 3 H. L. 330 (1\$6S).

HARV. 375 
formulae to be used. There was, however, general agreement that a negligent person should be liable for a particular harm only if it was a "natural and proximate" or "direct" result, and in determining this, the fact that a number of human acts intervened between the negligence and the catastrophe was thought to be important. The third difficulty arose from the fact that the common law gave greater protection against physical harm to a person and to his things and against harm to his reputation than it gave against harm to his economic security generally. Thus one who negligently harmed another's horse or, even without negligence, damaged another's reputation was liable, while one who by negligent misrepresentation caused another to give credit to a third person who thereby suffered loss, was under no liability. Cardozo's contribution to the law of torts lay principally in clarifying the general subject of negligence and in extending the liability for negligently causing pecuniary loss.

\section{MacPherson v. Buick Motor Company}

His first great opinion was rendered in MacPherson v. Buick Motor Company. ${ }^{3}$ The plaintiff was injured by the collapse of a defective wheel on an automobile which he had purchased from a retail dealer. The defendant had manufactured the car but had purchased the wheel from another manufacturer and had been negligent in failing to ascertain the defect. Aside from precedent, it would seem fairly clear that under the ordinary principles of negligence, more fully discussed later, the defendant should be liable since a defective wheel on an automobile is obviously a source of danger. A priori, the fact that the identity of the persons likely to be hurt could not be known would seem to be immaterial.

The difficulties related back to 1842 when, in the case of Winterbottom v. Wright, ${ }^{4}$ the Court of the Exchequer held that a person who had contracted to supply mail coaches for the Postmaster General and to keep them in repair was not liable to a driver hurt when one of them collapsed, although the plaintiff averred in his declaration that the defendant had so negligently disregarded

3 2I7 N. Y. 382 , III N. E. I050 (I916).

4 10 M. \& W. $109(\mathrm{Ex}, 1842)$.

376 HARV.

394 YALE

cor. 24 
his contract that the coach was dangerous because of latent defects. Members of the court could see no relation between the defendant's duty to the Postmaster General and his liability to the injured driver. "Privity" was absent. There was a mere failure to perform a duty to the Postmaster General. A breach of contract with one could not be made the basis of an action of tort against another. Furthermore, an infinity of actions might follow.

This case was followed by a long train of cases applying and to some extent limiting the doctrine. In New York the courts had refused to apply the rule to the situation where one not the immediate purchaser had been poisoned by using belladonna from a bottle which the defendant had erroneously labeled extract of dandelion.5 Nevertheless, the court accepted the reasoning of Winterbottom v. Wright, distinguishing it by the fact that the defendant was a dealer in things "imminently dangerous to life" and had affixed a false label. This and other decisions continued to reiterate the rule of nonliability, making only somewhat narrow exceptions to it. The results of the American authorities were perhaps best summed up by Sanborn, J., in Huset v. Case Thresking Machine Company. ${ }^{\circ}$ He stated that a manufacturer is not liable for harm caused by an article put on the market in such form as to be dangerous to third persons, except where it is imminently dangerous to life or health and is intended to "preserve, destroy, or affect human life" (in practice limited to foods and explosives), or where there is "privity" between the parties, as between the possessor of land and an invitee upon his premises, or finally where the defendant actually knew of the defect. With the manufacturer cases should be classed the contractor cases, that is, those in which a contractor negligently builds a structure which, after being taken over by the owner of the premises, causes harm to a third person by its collapse or otherwise. Here, again, the same technique was employed and the negligent contractor exculpated from liability because, using the language of causation, the possession of the owner had intervened between the negligent

\footnotetext{
5 Thomas v. Winchester, 6 N. Y. 397 (I852).

- I20 Fed. 865 (C. C. A. Sth, I903).
} 
act and the harm. It is to be noted that in all of these cases not within the narrow exceptions, the injured person normally would have no redress, since the duty of examination for defects by the retail dealer in chattels and by the owner of a building could be satisfied by a comparatively casual inspection.

That the results of the cases were both unjust and out of line with negligence principles seems obvious now. Writers had frequently called attention to the anachronism, ${ }^{7}$ but a great majority of courts accepted it. It is true that the New York courts had gone somewhat further than other courts, but the principle that liability should be based upon the existence of a substantial chance of harm and not upon the kind of commodity which had been put into circulation had not been accepted. In the Buick case, speaking for a court which granted recovery, Cardozo exposed the fallacy of the limitations.

"If the nature of the thing is such that it is reasonably certain to place life and limb in peril when negligently made, it is then a thing of danger." Knowledge that the danger will be shared by others than the buyer " may often be inferred from the nature of the transaction." "In such circumstances, the presence of a known danger, attendant upon a known use, makes vigilance a duty." "Beyond all question, the nature of an automobile gives warning of probable danger if its construction is defective." "It was as much a thing of danger as a defective engine for a railroad. The defendant knew the danger. It knew also that the car would be used by persons other than the buyer. This was apparent from its size; there were seats for three persons. It was apparent also from the fact that the buyer was a dealer in cars, who bought to resell." "The dealer was indeed the one person of whom it might be said with some approach to certainty that by him the car would not be used. Yet the defendant would have us say that he was the one person whom it was under a legal duty to protect."

I Especially Bohlen in a series of articles entitled, The Basis of Affrmatit' Obligations in the Law of Tort (r905) 53 U. OF PA. L. REv. 209, 273, 337, upon which Cardozo drew in the Buick case. It was characteristic of Cardozo to give more weight than do most judges to opinions not expressed in books with stlff covers. Jeremiah Smith in the classroom anticipated the Buick decision by at least fifteen years.

378 HARV.

COL. 26 
"Subtle distinctions are drawn by the defendant between things inherently dangerous and things imminently dangerous, but the case does not turn upon these verbal niceties. If danger was to be expected as reasonably certain, there was a duty of vigilance, and this whether you call the danger inherent or imminent."

Cardozo's logic, which could not be refuted, and the prestige of the New York court succeeded where professorial criticism had been ineffective. It would not be true to state that the case has been universally followed. Some of the American courts have not been willing to change their habits of thought, or at least of decision, and in the cognate situation where a flimsy structure negligently erected by a contractor has caused harm to a third person after its acceptance by the owner, the change has been slow. ${ }^{8}$ But there is little doubt of the ultimate complete acceptance of Cardozo's viewpoint. Winterbottom v. Wright has been discredited in the land of its birth ${ }^{3}$ and apparently without the prophesied distressing consequences. The questions which Cardozo with characteristic caution, or perhaps to gain acceptance by the court of his opinion, excluded from the decisionwhether the liability of a manufacturer would extend to harm to chattels; ${ }^{10}$ whether the maker of a defective component part supplied to a manufacturer would be liable to the ultimate user ${ }^{21}$ have been resolved by subsequent decisions in favor of liability. It is probable that the next generation of law students will be led to look upon Winterbottom v. Wright and its immediate successors only as an interesting illustration of judicial frailty, or if they favor the economic interpretation of judicial opinion, as an example of temporary protective judicial legislation given the manufacturers until they became sufficiently strong as a group to pay for the consequences of their employees' mistakes.

8 Ford v. Sturgis, I4 F.(2d) 253 (App. D. C. 1926). A change of attitude is indicated in Griffith v. Atlantic Refining Co., $305 \mathrm{~Pa} .386,157$ Atl. $79 \mathrm{I}$ (193I).

9 M'Alister v. Stevenson, [1932] A. C. 562, reviewed by Pollock in (1933) 49

L. Q. Rev. 22; Grant v. Australian Knitting Mills, [1936] A. C. 85.

10 Genesee County Patrons Fire Relief Ass'n v. L. Sonneborn Sons, Inc, 263

N. Y. 463,189 N. E. $55 I$ (I934) (harm to a barn).

11 Smith v. Peerless Glass Co., 259 N. Y. 292, I8I N. E. 576 (1932).

27 COL. 


\section{The Wagner Case}

Wagner v. International Railway Company ${ }^{12}$ involves substantially the same principle as the Buick case but has its own difficulties. The plaintiff and his cousin were on one of the defendant's interurban cars when the cousin was thrown from it by the defendant's negligent act. The train was stopped and the plaintiff, going through the darkness to search for his cousin, fell and was injured.

That the defendant was negligent and that the negligence resulted in harm was clear, but there was difficulty as to precedents. And the case also presented the further problem of deciding whether the defendant could reasonably have anticipated harm to a rescuer. Previous decisions were far from conclusive. Liability had been imposed in cases in which a person observing another about to be harmed by the defendant's negligence had intervened at the expense of harm to himself. ${ }^{13}$ These, however, differed from the Wagner case in which the defendant's act had been done before the plaintiff went to the rescue, and the plaintiff was not acting "instinctively," apparently an important consideration in other cases where recovery had been allowed. There were also cases where a person had been injured in protecting himself or his property from the effect of a negligent act of the defendant. Here, however, the defendant could have anticipated harm to the plaintiff, and the doctrine of avoidable consequences, by which the owner could recover for harm to his things only if he made reasonable efforts to prevent the harm, would seem to make it clear that he was entitled to recovery. However, some courts had refused recovery even in this case, ${ }^{14}$ and in other cases where the plaintiff was a stranger attempting to rescue endangered property of third persons recovery had been more widely denied..$^{16}$

12232 N. Y. 176, I33 N. E. 437 (r92I).

13 E.g., Eckert v. Long Island R. R., 43 N. Y. 502 (I87I).

14 Seale v. Gulf, C. \& S. F. Ry., 65 Tex. 274 (1886); Crowley v. West End, I49 Ala. 613,43 So. 359 ( 1907 ). Assumption of risk has been frequently used as a bar to recovery, as in Cutler v. United Dairies, Ltd., [r933] 2 K. B. 297.

Is Cook v. Johnston, 58 Mich. 437, 25 N. W. 388 (I8S5); Eversole v. Wabash R. R., 249 Mo. 523, I55 S. W. 419 (I913). 
The decision in the Wagner case, where recovery was allowed, was therefore opposed in principle to many existing decisions and went further than any case had previously gone. Again, however, Cardozo's logic, even when divorced from the persuasive appeal contained in the phrase "danger invites rescue," seems inescapable. It places responsibility for the consequences of a choice made by the plaintiff upon the one who put him in the dilemma of choosing between safety for himself or aid to a friend. The fact that the plaintiff had an opportunity to consider the alternatives would seem to have no bearing upon liability, provided the plaintiff acted rationally. Witness the numerous cases in which the plaintiff comes to harm in an effort to escape a greater harm threatened by the acts of the defendant. The reasoning which gives one a privilege to intervene to defend a third person from an attack is also applicable.

The importance of this case and of the Buick case is that they focus attention upon the risk of harm and not upon the manner by which it is caused or the number of events intervening between the defendant's act and the catastrophe. The older phrases which were used to describe the situations and to delimit liability are abandoned in favor of the realistic viewpoint by which anticipation of harm and not the proximity in point of space or time or the number of intervening events is of sole importance. The theory that for some undefined reason the intervening acts of human beings may "insulate" the defendant's negligence from its consequences becomes no longer tenable. The sole question is whether there is sufficient risk.

\section{The Palsgraf Case}

The decision in the Palsgraf case ${ }^{16}$ was a natural development of the theory underlying the two preceding cases, the implications of which were not perhaps fully perceived by the profession. The very fact that in the Palsgraf case judgment was given for the defendant accentuates rather than throws doubt upon the underlying theorem of the three cases, which is that risk not merely

10 Palsgraf v. Long Island R. R., 248 N. Y. 339, 162 N. E. 99 (1928).

$29 \mathrm{COL}$.

YALE 399

HARV. $38 \mathrm{I}$ 
creates the existence of liability but defines its limits both with reference to the person injured and to the harm.

In this case the plaintiff, a woman, was sitting in a railroad station some distance from the track. Two of the train guards, in assisting a passenger to reach the platform of the already moving train, clumsily knocked from his arms a small package, which, although its appearance did not so indicate, contained fireworks. The package fell beneath the wheels of the train and an explosion resulted, causing scales near which the plaintiff was standing to be thrown against her. On a finding by the jury that the guards were negligent, judgment for the plaintiff was entered both in the trial term and in the Appellate Division. The Court of Appeals reversed the judgment by a four to three decision.

Cardozo, speaking for the majority, reasoned that the plaintiff might "claim to be protected against unintentional invasion by conduct involving in the thought of reasonable men an unreasonable hazard that such invasion would ensue " but " if no hazard was apparent to the eye of ordinary vigilance, an act innocent and harmless, at least to outward seeming with reference to her, did not take to itself the quality of a tort because it happened to be a wrong, though apparently not one involving the risk of bodily insecurity, with reference to someone else." "Wrong to another cannot be the basis of the plaintiff's claim and even less a wrong to a mere property interest." "Negligence like risk is thus a term of relation." "The risk reasonably to be perceived defines the duty to be obeyed and risk imports relation." "Negligence in the abstract apart from things related is surely not a tort." "Affront to personality is still the keynote of the wrong." "The victim does not sue derivatively or by right of subrogation to vindicate an interest invaded in the person of another." "He sues for breach of a duty owing to himself. The law of causation remote or proximate is thus foreign to the case." Andrews, on the other hand, speaking for the dissent, said that "it is the act itself, not the intent of the actor that is important "; that "where there is the unreasonable act and some right that may be affected, there is negligence"; that this is "a wrong not only to those who hap. 
pen to be within the radius of danger but to all who might have been there." Yet "the danger must be so connected with the negligence that the latter may be said to be the proximate cause of the former." One must be " a substantial factor in producing the other." There must be "a direct connection between them without too many intervening causes, a natural and continuous sequence between cause and effect." "It is all a question of expediency. There are no fixed rules to govern our judgment." "There is in truth little to guide us other than common sense."

The two opinions make the issues clear. They crystallize the arguments which have surrounded such situations until the subject of legal cause as an element in liability for negligence has become a stench in the nostrils of Law Review editors, the arguments which have caused some judges, hopeless of understanding them and with characteristic faith in the ability of the jury to untangle that which the judge cannot, to leave the whole matter to the jury without further statement than that a negligent defendant is liable if he was the legal cause of the harm. The result sought by Cardozo, Andrews, and all the others is a formula which with a fair degree of definiteness will mark the boundary between liability and nonliability and be consistent with our sense of justice as this has been developed in imposing liability in negligence cases. ${ }^{17}$ Before appraising the utility of the two opinions for this purpose, it may be well to indicate the three patterns into which fall negligence cases involving both the existence and the extent of liability.

First, where the defendant's act is one of a number of cooperating causes and where the harm would have happened irrespective of the defendant's act. This is illustrated where there are two fires, each of which is negligently started and which, combining, burn the plaintiff's house which would have been burned by either of the fires; or where the plaintiff's house is washed away by a flood caused either by the breaking of a number of negli-

1i Note, however, that Cardozo's test, by throwing the problem into one of a relational duty of care owed to the plaintiff, may give the court greater control of the case than does Andrews' view which, when the court finds that there was a duty to exercise care owed to some person, leaves to the jury the question whether the breach of such duty was a legal cause of harm to the plaintiff.

3 I COL.

YALE 4OI

HARV. $38_{3}$ 
gently constructed dams or by a combination of a poor dam and an extraordinary and unexpectable flood. In all such cases admittedly the defendant's act is not a cause of the result, using cause in the sense of necessary antecedent. Just as obviously, however, if there are a number of negligent acts any one of which would have caused the harm, unless all of the defendants are to escape liability, we must make each responsible, at least if one of the acts does not greatly predominate over the others. Thus, for instance, where a large group of rioters harms the plaintiff's house, we think it fair to impose liability for the entire harm upon each member of the group, even though the individual contribution to the riot is comparatively small. On the other hand, where a person is wounded coincidently by two persons acting separately, one of whom gives him a mortal wound, while the other causes only a scratch, we would think it unfair to hold the latter liable for a death resulting from loss of blood. It is in this type of situation that it is useful to say that the defendant is not liable unless his act is an appreciable or substantial factor; that is, unless, considering all the events and the relation between his act and the other acts cooperating in producing the result, we feel that his act had a substantial effect. Obviously we do not need the use of the words "proximate" or "direct" in connection with such cases; the problem of liability does not depend upon the succession of events. This situation is not involved in the Palsgraf case since there the only negligent acts done were by the defendant's servants and since their acts were important factual causes, however we may use that word.

The second group of cases involves only the question of damages. It is assumed in these cases that the defendant is a tortfeasor with respect to the plaintiff and the question is as to the extent of the harm for which he is liable. The type case is that where one negligently strikes another causing him immediate serious harm, as a result of which he is taken to a hospital and subsequently suffers further harm or dies because of intervening negligence or extraneous events, such as the burning of the hospital. With reference to this type of situation, the problem may be as to liability for the harm immediately ensuing upon the negligent 
act or for the harm which subsequently develops. As to the first, it accords with our general sense of justice that the tortfeasor should be liable irrespective of the unexpectedness of such harm. Thus where the defendant has negligently struck a person whose skull is so fragile that it is broken by the comparatively slight blow, all courts are agreed that the defendant is liable for the wholly unexpected breaking. This is true not only with reference to physical harm but also other forms of harm. If a person were negligently to incapacitate another who has a yearly earning capacity of a hundred thousand dollars, there is liability for the resulting loss though so great a loss could not have been anticipated. It may be that this is a possible explanation for the reaction of the King's Bench in its famous but doubtful decision of the Polemis case, in which the defendant whose workman negligently dropped a plank into the hold of a ship filled with gasoline vapor was made liable for the destruction of the ship resulting from the ensuing explosion. ${ }^{1 s}$ In this, as in other cases, the courts are agreed that the negligent person takes his victims as they are. With respect to harms resulting subsequently, as in the death from a hospital fire, the approach is similar to that used where the question is whether there is any liability and not its extent. Thus to use the method used by Cardozo, the defendant is liable for subsequent events which, after the tort has matured by impact, appear to be within the risk. To use the approach of Andrews, the defendant is liable for those subsequent events of which the impact is the proximate and natural or direct cause.

The third group of cases is that in which the Palsgraf case, the Buick case and the Wagner case fall and in which the defendant's negligence is a sine qua non or necessary antecedent of the accident, but in which the question still remains whether the defendant has committed a tort to the plaintiff.

There are perhaps three factors which are to be considered in determining whether the approach of Cardozo or that of Andrews is to be preferred in this type of situation.

I. Which is the more consistent with our sense of justice in the particular case?. Personally, I would find it hard to answer this

18 In re Polemis, Furness, Withy \& Co., Ltd., [Ig3I] 3 K. B. 560.

33 COL.

YALE 403

HARV. 385 
question. An innocent person has been hurt; some one must bear the loss. The defendant's employee was negligent, although only slightly. The fact that neither he nor his innocent employer had reason to believe that a momentary clumsiness might lead to great liability is not of itself sufficient to deny it. The law is not squeamish about imposing liability upon even innocent wrongdoers, as the defamation and conversion cases show; only by the unlawful act of the jury can damages be minimized when fault is slight or absent. On the other hand, it is universally agreed that the fact that a loss has resulted from the defendant's negligent conduct is not enough to impose liability. A momentary lapse does not transform the defendant into a man whom we wish to punish. $\mathrm{He}$ is not disentitled to take advantage of rules which may limit his liability.

2. Which view is more consistent with the underlying theory of negligence? On the existing cases, this issue seems clear. Even intentionally bad acts do not necessarily result in liability to the actor for harm thereby caused. One who, while carefully driving an automobile with which he is kidnapping a child, runs over and kills a pedestrian is not civilly liable for the death, even though he may be guilty of murder. In the Palsgraf case, the defendant's act was wrongful only because it created a risk - that is, an unreasonable risk - of harm to the package. Prima facie at least, the reasons for creating liability should limit it. In fact, whatever expressions have been used to define the limits of liability in this type of case, expectability has always been in the background. Rules have frequently cut liability below this point. Thus in some states, New York included, there is no liability for negligently causing a mental disturbance which later, through internal causes, leads to physical harm. ${ }^{10}$ The New York fire

10 The position of the New York court was made somewhat doubtful by an opinion announcing a decision for the plaintiff who fainted upon the sidewalk immediately after a slight impact with her car, the fall causing injury. Comstock v. Wilson, 257 N. Y. 23x, 177 N. E. 43I (193I). The New York Law Revision Commission in 1936 submitted a draft of a statute providing that "recovery shall not be denied merely because such bodily injury or wrongful.death was brought about through fright or shock without physical contact or impact." N. Y. L. REVISION Comar. REP. (I936) 377. The legislature rejected the recommendation. 
rules, and the rule in the waterworks cases (discussed below), are further illustrations of this. However, except as to consequences immediately following the tortious impact, seldom have the courts extended liability beyond the field in which there is an appreciable risk of harm. Interpretation of the innumerable statutes fixing a standard of care, such as those defining the rules of the road, is such that an injured person is protected only if it is found that the statute makers intended to protect a person in his class against a statutory violation, and then only if the harm he suffered is within the risk which the statute was intended to minimize. Likewise the owner of a dog, known to be vicious, who would be liable without fault if it should bite a person after escaping, is not (apart from statute) liable to a person whom the dog clumsily knocks down, since the risk created by the dog was only that of being bitten. ${ }^{20}$ I would assume that a court which would impose liability for harm resulting from an unexplained explosion of a large quantity of explosives, ${ }^{21}$ would not hold liable the possessor of a pile of boxed explosives if, without his negligence, the boxes were to fall upon and crush the foot of a privileged visitor ignorant of the danger inherent in the pile. The risk is one of explosion and not of crushing.

In the modern negligence cases, the fact that the harm is directly caused by an intervening act of a stranger induced by the defendant's negligent conduct prevents the imposition of liability upon the first wrongdoer only if the type of intervention was not within the risk. Thus if the defendant were to leave open a bulkhead adjacent to a slippery sidewalk and a crowd of rowdies so jostled the plaintiff that he fell into the bulkhead, the defendant would be liable for the harm; if, however, the plaintiff were pushed in by an enemy, there would be no liability.22 The risk was that a

20 Koetting v. Conroy, 223 Wis. 550, 270 N. W. 625 (1936). In Scribner v. Kelley, 38 Barb. I4 (N. Y. I862), where the plaintiff's horse was frightened by the defendant's elephant which was being led on the turnpike, the court said that the horse was not frightened by the elephant qua elephant, but only as a large animate object. Quaere.

21 Exner v. Sherman Power Const. Co., 54 F.(2d) 5 10 (C. C. A. 2d, 1931).

22 Miller v. Bahmmuller, I24 App. Div. 558, I08 N. Y. Supp. 924 (Ist Dep't Ig08).

35 cor. 
traveler might slip in or be inadvertently pushed in, and not that he might be thrown in. On the other hand, one who negligently knocks over a wagon filled with goods would be liable to the owner for losses caused by thievery which the collision made expectable.

These results represent the normal reaction of courts to the various situations where the basic wrong is the creation of an unreasonable risk. Cardozo rationalizes the results, making them consistent with the fundamental conception of negligence. Andrews, as do all the philosophic proponents of the legal cause approach, rationalizes the results only by going back to the elementary basis of all proper legal decisions, by stating that the test is whether the result found by the court accords with our sense of justice. If we are to have the Chancellor's foot as a unit of measurement, we may reasonably expect the Chancellor to have feet of normal size; the result reached by Andrews is contrary to the great weight of American decisions, as I understand them.

3. The final question is which of the two approaches can be more easily applied. If we accept the Andrews opinion at its face value there can be little said in favor of its ease of application. It is difficult to apply a rule which is based upon " a rough sense of justice "; which " arbitrarily declines to trace a series of events beyond a certain point"; which is based upon "practical politics"; which has " no fixed rule to govern our judgment"; which gives "little to guide us other than common sense" or, if there are guides, a rule by which the answer depends upon whether there was "a natural and continuous sequence between cause and effect." We certainly do not desire arbitrariness, and the term "practical politics" as applied to negligence has no very definite connotation. No reason is obvious, and none is given, why intervening events, time or space should play a part, aside from their expectability. One who leaves percussion caps where he should know a child will find them should not be and is not relieved from liability for harm where the child who finds them places them with his treasures carefully concealed from adult eyes and six months later trades them to another child in another city who, in playing with them, causes an explosion, harming whom you will. Even

23 Brower v. New York C. \& H. R. R. R., 91 N. J. L. 190, 103 Atl. 166 (1918).

388 HARV.

406 YALE

COL. 36 
Andrews invokes expectability in the Palsgraf case by asking what might be expected from the dropping of a package, but in order to make the result expectable, he begins his "chain of events" or his "direct sequence" by assuming an explosion as the beginning of the series. Those using the test of directness are merely playing with a metaphor; if directness is meant to connote the comparative absence of external forces not set in motion by the defendant, it is not responsive to the decisions either as a test of inclusion or exclusion. The phrases "natural and continuous sequence" and undeflected "stream of events" mean nothing except so far as they have reference to expectability by persons who know some of the facts but not all of them, - that is, the reasonably prudent and intelligent person at the time and place and this of course brings us back to risk. The connection between the act of the person who fails to insert a cotter pin in the mechanism of an automobile and the harm to a guest in the car six months later in another part of the country (facts corresponding to the Buick case), is direct only in the sense that the result is within the risk created by the failure. If we go beyond Andrews and use other well-known phrases and similes, we fare no better. Has the defendant's force been continuously active? In this use of the word, active is again but a metaphor, unless by "active" we mean pregnant with danger. Was the defendant's act a condition rather than the cause? This phrase can be interpreted only if we know what distinguishes condition from cause, or in other words, if we have already answered the problem. For many years chains and nets were supposed to have something to do with liability and although Andrews preferred not to use them, I suggest that by their use the situation is described no more inaccurately, if less vividly, than by the phrases which have displaced them in the favor of the modern Andrews School.

In place of word paintings and purported reasons, Cardozo in the three opinions here reviewed substituted " risk," a word which has a meaning, not merely to the legal student, trained in the use of fictions, but also to the jurors to whom, in most cases, the decisions will be entrusted. If it is complained that "risk" is a word of no definite import, it may be answered that at least it is 
more descriptive than the other phrases used, which in this type of case at least, always resolve themselves ultimately into rules dealing with expectability. If it is observed that the risk conception limits liability in situations like the Palsgraf case, it may be answered that it also widens it as in the Buick case, and that in both cases it makes the penalty fit the offense of the negligent person. It is consistent with this approach to carry liability further when the risk is to many and not merely to a few, a result which would be illogical were we relying merely upon "an unbroken stream of events" to carry the plaintiff to his destination of recovery.

It is difficult to forecast the ultimate effect of the Palsgraf decision. In Smith v. London \& Southwestern Railway, Brett, M. R., in the Court of Exchequer, ${ }^{24}$ made the suggestion that there should be no liability except where there has been negligence to the plaintiff. This idea was definitely rejected by the Court of the Exchequer Chamber. ${ }^{25}$ Much later the point of view was developed and fully expounded by Bingham. ${ }^{20}$ Judge Peaslee, in denying recovery for the death of an unseen trespasser in an accident which was negligent as to others, applied the principle with characteristic clarity and force. ${ }^{27}$ Cardozo's opinion has received powerful support from the Second Circuit Court of Appeals. ${ }^{\text {as }}$ But it is difficult for the courts and lawyers to avoid using familiar phraseology, and apparently the older terms have much charm for the profession. Text writers likewise fear to depart from long accepted usage. Perhaps to provide a transition period in which the courts might use either approach, the Restatement of Torts, first adopting to the full the theory of risk, ${ }^{20}$ at a later stage recants and presents a confusing series of "superseding causes,"

24 L. R. 5 C. P. 98 (1870).

25 L. R. 6 C. P. I4 (1870).

26 Legal Cause at Common Law (1909) 9 Coc. L. Rev. 16, 136, 154.

27 Garland v. Boston \& M. R. R., 76 N. H. 556, 86 Atl. I4I (I9I3).

28 Sinram v. Pennsylvania R. R., 6I F.(2d) 767 (C. C. A. 2d, 1932). Strang support is also given by Wickhem's opinion in Waube v. Warrington, 216 Wis، 603, 258 N. W. 497 (1933).

$29 \S 28 \mathrm{I}$.

$30 \$ \$ 440-42$. In fairness, I should point out that the general statement of legal cause in $\$ 43 \mathrm{I}$, I regard as accurate. "The actor's negligent conduct is a legal cause of harm to another if (a) his conduct is a substantial factor in bringing about the 
may cut off liability. The courts, like the Restatcment, have frequently tried to ride two horses, but I have faith that the simplicity, logic, and justice of the approach made prominent by Cardozo will ultimately prevail.

\section{The Moch Case}

After the Buick, Wagner and Palsgraf cases, Mock v. Rensselaer Water Company ${ }^{31}$ is an anticlimax, but discussion of it is necessary to complete the picture. Cardozo, writing for a unanimous court on a motion to dismiss in the nature of a demurrer, denied recovery against a waterworks company which, after notice of the existence of a fire, had failed to supply to the street mains the pressure which it had contracted with the city to supply. As a result, the plaintiff's building was destroyed. The court disregarded, as grounds for liability, the theories that there was a contract for the benefit of the plaintiff, and that the defendant had committed a breach of statutory duty. It further denied that there was the basis of a tort action, even though it were assumed that the defendant had been negligent in failing to maintain water pressure.

That the result of the Moch case probably is sound must be admitted, not merely because of the failure of the plaintiff to allege negligence in the performance of the contract, but also because the overwhelming weight of authority in this country has denied liability under similar conditions. The court might have dealt with it as a special waterworks situation as it had dealt with the spread of fire. ${ }^{32}$ It might have placed the result wholly upon

harm, and (b) there is no rule of law relieving the actor from liability because of the manner in which his negligence has resulted in the harm." This provides for situations in which it is necessary to use the idea of substantial factor and also for the exceptional cases where there is a liability-limiting rule, as is true in New York with reference to the spread of fire, and harm resulting from mental shock: without impact. The sections dealing with superseding cause, however, are illusory; no illustration of a superseding cause is given which would not come within an exposition of the limits of undue risk to the injured person.

31247 N. Y. 160, 159 N. E. 896 (1928).

32 Cardozo did not dissent when the court accepted as settled the idiosyneratic but long-existing New York rule by which the liability for spread of fire is limited to harm to adjacent land except where the fire leaps an intervening street or vacant spot: See Homac Corp. v. Sun Oil Co., 258 N. Y. 462, 180 N. E. 172 (1932).

39 COL.

YALE 409

HARV. 39I 
the assumed ground of public policy that the burden which would be placed upon water companies by allowing recovery would be too great. Had Cardozo said that the court was coerced by an almost unanimous line of liability-denying decisions, not only in New York but elsewhere, one would have little heart for disagreement with the judgment of a court which has not been too insistent upon adherence to stare decisis in tort cases. The fact that the previous cases denying recovery had been largely based upon the failure by the courts to recognize that the situation had a tort and not a contract base would not necessarily be sufficient to require a court to depart from settled authority in the absence of a strong feeling that the older line of cases created an obvious injustice.

However, instead of pursuing his accustomed method of facing the realities, Cardozo speaks of the failure of the water company as if it were merely a failure to confer a benefit upon the injured householder, and in denying liability relies upon the recognized principle that one is under no duty to confer a benefit upon another. Of course, the plaintiff did not complain of the failure to receive a benefit. His real ground was that, because of reliance upon the undertaking of the water company to maintain an adequate pressure at the hydrants, the city had failed to make other provision for the protection of its citizens, and the plaintiff, among others, being lulled into a false sense of security, had failed individually to take measures to protect his property. In substance, the situation does not differ from that where a train cuts a fire hose or blocks a street, so that the fire department cannot extinguish a fire. In both cases the defendant has prevented a third person from rendering assistance. Where the act is after the beginning of the fire, there is an immediacy of need which does not exist in the waterworks situation, yet since it is well known that fires occur from time to time in any town large enough to afford waterworks, there would seem to be such a substantial risk of harm to the group of which the plaintiff is one as would make such cases directly in point. The risk to the individual plaintiff is less, but the chance of harm to any one of a large number is great. Furthermore, in the Moch case, it was alleged that the defendant had failed to keep up the pressure after know- 
ing of the fire. It had been held before the Moch case, as it has been held since, that the negligent breaking of a water main may be the basis of a cause of action in favor of a householder who had been thereby deprived of the assistance of the fire department in quenching a fire. ${ }^{33}$ Analogous are the cases where a railroad has undertaken more than its legal duty in supplying at a railroad crossing a watchman upon whose presence travelers frequently using the crossing have relied, ${ }^{34}$ and those where an agent in charge of a building has failed to keep it in repair, as a result of which a third person is injured. In these cases where the wrong consists of a failure to act, the older viewpoint was that since there is mere "nonfeasance" and no direct obligation to the injured person, there can be no liability to him. The fallacy of this older point of view has been today generally exploded, and the $M$ Ioch case furnished a suitable opportunity for disposing of some of the earlier cases in which the New York courts had been reactionary rather than forward-looking. ${ }^{35}$

Although Cardozo cites MIacPherson v. Buck and by implication his criticism of Winterbottom $v$. Wright, his language is not dissimilar to that of Lord Abinger in the latter case. Both judges feared that an infinity of actions might follow and that "the assumption of one relation will mean the involuntary assumption of a series of new relations inescapably hooked together." Of course, the fear that the failure to perform a contract with another will necessarily result in liability to a third person harmed by its breach is wholly unfounded. Had the court found it desirable to impose liability upon the waterworks company, we may imagine that Cardozo's language would have been substantially similar to that in MacPherson v. Buick. Deciding as the court did, however, the difference in the state of the authorities and the possible difference in policy would have afforded a sufficient reason for a difference in result.

33 See the cases cited in Gilbert v. New Mexico Construction Co., 39 N. MI. 216, 44 P.(2d) 489 (r935).

34 Erie R. R. v. Stewart, 40 F.(2d) 855 (C. C. A. 6th, 1930).

35 See (I916) I So. L. Q. I6, where I briefly discussed the whole matter, being then, as now, perhaps overdesirous for symmetry. 


\section{MisRepResentations}

\section{Glanzer v. Shepard}

From the standpoint of the market place, the most important cases are those in which Cardozo dealt with misrepresentations. The first great opinion here is that in Glanzer v. Shepard. ${ }^{\text {so }}$ A bean merchant requested the defendants, public weighers, to weigh beans which he had sold, make a return of the weight and furnish the buyer with a copy. The defendants did as bidden, but carelessly certified the weight to be greater than that which in fact it was. One copy of the return was sent to the seller and a duplicate to the buyer, the plaintiff. On discovering the discrepancy, the buyers, who had already paid on the basis of the false weight, brought suit against the defendants to recover the amount of the overpayment.

Were this a case involving physical harm, there would have been no shadow of doubt as to defendant's liability. ${ }^{37}$ As it was, however, Cardozo's opinion that liability should be imposed was an innovation. The results of the decisions up to that time may be thus summarized. A fraudulent statement by one of two bargaining parties to the other, resulting in the diminution of the other's assets, was the basis of an action of tort. Likewise, in many states, particularly in land cases, the results, although not the language, of the decisions created liability to the other party for

36233 N. Y. 236, r35 N. E. 275 (1922).

37 The cases involving harm resulting from a negligent verbal misstatement of fact are not numerous. However, there are innumerable situations where the basis of liability is an implied representation of safety, as is indicated by the fact that in them, an exposure of the facts would have prevented liability. In this group fall cases involving the liability of a master to his servant or of a landowner to a business guest for concealed dangers which the master or landowner would have discovered by the use of due care. Likewise the liability of a manufacturer is based on the fact that he has caused harm by negligently permitting to be placed in the channels of trade a thing which has a deceptive appearance of innocuotisness.

In MacKown v. Illinois Publishing and Printing Co., 289 Ill. App. 59, 6 N. E.(2d) 526 (1937), recovery was denied in an action against a newspaper by a reader who was harmed in using an improper remedy negligently recommended by a staff writer. The court, failing to recognize the distinction between physical harm and harm to pecuniary interests, based its opinion upon the New York cases culminating in the Ultramares decision. 
statements which were honestly made but which the speaker should have known were either untrue or doubtful..$^{33}$ In a few states, the tort action took the place of an action for breach of warranty and recovery was allowed irrespective of reason to know of the falsity. ${ }^{39}$ However, there was substantially no authority for holding that an action would lie against one not a fiduciary who by negligent misrepresentations had caused no more than pecuniary loss to one not contracting with him. In the situations most nearly analogous, that is, where an attorney or abstracter had negligently made an abstract upon which a third person had relied, the great weight of authority denied recovery. The denial of liability was beginning to be broken down by inroads in special types of cases, ordinarily through the common-law device of a fiction. Thus an agent who had misrepresented his authority, even without negligence, was subject to liability on the theory that he had warranted his power to act; again, one against whom the doctrine of estoppel could be employed was held liable for a loss resulting even from his innocent and nonnegligent statements. The prevailing rule that an attorney or abstracter who had negligently prepared an abstract of title was liable only to his employer had been invaded, in some states by using the undisclosed principal doctrine or the rule of Laverence v. Fox, and in others even without these subtleties. Again, attention had been called to the anomalous distinction between liability for causing harm to persons and things and the nonliability for causing loss to a pecuniary interest.

The time was ripe for taking advanced ground and in Glanzer v. Shepard this ground was taken by the use of every dialectic weapon which could be brought to bear. The representation was made directly to the plaintiff; the defendant acted " for the very purpose of inducing action "; he was exercising a common calling in which one must act carefully if at all, even though acting gratui-

38 Various forms of language are used to conceal the basis. A familiar form is to state that "one who falsely asserts a material fact, susceptible of accurate knowledge, to be true of his own knowledge is fraudulent." Sse Chatham Furnace Co. v. Moffatt, I47 Mass. 403, I8 N. E. I68 (I888); Hadcock v. Osmer, 153 N. Y. 604,47 N. E. 923 (I897) ; Cabot v. Christie, 42 Vt. I2I (1869).

39 Aldrich v. Scribner, I54 Mfich. 23, II7 N. W. 58I (Ig0S).

43 COL.

YALE $4 \mathrm{I} 3$

HARV. 395 
tously; title searchers are liable if they deliver a certificate directly to the person who has to act upon it; the liability is based not merely on careless words but on " the careless performance of a service, the act of weighing "; the situation is not different in principle from that in Lawrence v. Fox or that where the sender of a telegram is treated as the agent of the recipient for the purpose of allowing the recipient to sue for negligent transmission. "The defendants, acting not casually nor as mere servants but in the pursuit of an independent calling, weighed and certified at the order of one with the very end and aim of shaping the conduct of another. Diligence was owing not only to him who ordered, but to him also who relied."

Much of Cardozo's argument can be minimized. There is not here the frankness displayed in most of his other opinions. He ignored the distinction which made the case an advance over those which had gone before. Those exercising a public calling had previously been made liable to those not employing them only for physical harm, for example, surgeons employed by others than the patients. Furthermore, the weigher was not engaged in a public calling of the type to which special rules apply, if indeed his calling was in any sense public. The abstracter cases which he cited represented the minority view and most of them imposed liability on contract grounds. That the error was made in weighing and not in representation was obviously immaterial, nor does it appear whether the error was in weighing or in recording the weight.

Nevertheless, it is a successful and powerful opinion. The cataloguing of the diverse situations in which recovery had been allowed makes clear the fundamental principle and the futility of widely diverse rules for situations essentially similar. The shallowness of the various pretexts used by the courts to advance from point to point is revealed. We are made to feel that although minute and inconsequential differences are the materials upon which the law grows, yet they can be disregarded when its growth has been completed; that the exploratory lines of the sketch can be erased when the design for the finished picture has been perceived.

It is not until we come to the last sentences of the opinion that 
we receive warning that the recognition of a principle does not involve its universal application. Principles by which liability is created are frequently more easily discernible than the limits to which equitably they should extend. Thus in this opinion Cardozo stated the principle that there should be liability for the negligent use of language involving no physical harm, but immediately served notice that it might be of limited application and that categories which customary methods of decisions have created cannot properly be completely ignored. Such categories are frequently built upon subtle differences which feeling and not logic will reveal. Thus the ancient law of defamation with its absolute liability for the use of language even when not on its face defamatory, still has vitality in a world in which language, not defamatory, ordinarily imposes no liability even when negligently uttered. Only when habits of thought are substantially changed is it time for a complete revolution.

The succeeding cases demonstrate the vulnerability of the generalization which might have been made from a hasty reading of Glanzer v. Shepard. The following year the New York court decided that a firm furnishing ticker service for brokerage offices should not be liable for loss caused to a broker's customer who had relied upon its erroneous and negligent report of a decision of the Supreme Court. On demurrer, in a memorandum opinion, the judgment of the Appellate Division was affirmed, the only clue to the reasons being in a statement that the one furnishing ticker service was in the same position as the publisher of a newspaper. ${ }^{40}$ In the next case involving a similar issue, ${ }^{11}$ the court granted recovery against a railroad which had contracted to store the goods of a consignee and which in response to his request for information of the location of the goods for insurance purposes negligently gave erroneous information, with the result that he could not collect the insurance upon the goods when they were burned. Andrews, speaking for the court, explicitly denied the existence of broad implications from the Glanzer case. After intimating that in the ticker case recovery was defeated because the plaintiff had no

10 Jaillet v. Cashman, 235 N. Y. 5II, I39 N. E. 7I4 (1923).

41 International Products Co. v. Erie R. R., 244 N. Y. 33I, I55 N. E. 662 (1937).

45 COL. .

YALE $4 \mathrm{I} 5$

HARV. 397 
right to act on the belief that the defendant had used care in spreading the report, and pointing out that the relations between parties which will create a duty of care and liability for a failure to exercise it cannot be precisely defined, he said: "We have confined our decision to the precise issues before us." This would seem to be the extreme of caution since, because of the bailorbailee relation in the case, the decision was no advance over preexisting law. This cautious language is, however, used as a basis for denying recovery in a case ${ }^{42}$ in which the court finds the decisive ground for denying recovery to be the fact that the defendant had no reason to believe that his erroneous statement would cause the plaintiff to act in the way in which he did. There was no advance made in the next case in the series ${ }^{43}$ although recovery was allowed. A trustee for an issue of bonds was made liable to a bondholder purchasing the bonds on the strength of the defendant's certificate that collateral had been deposited with him. The relation of trustee and cestui que trust which existed between the parties would have been a sufficient basis for recovery. Further, the result could have been reached on authority by use of the estoppel technique; that is, the court could have held that the trustee was estopped to deny that he had the collateral and hence would be dealt with as if he had it.

\section{The Ultramares Case}

In spite of the strait jacket into which the principal of liability for loss caused by negligent language hád been placed by the preceding cases, when a divided Appellate Division decided for the plaintiff in Ultramares Corporation v. Touche, ${ }^{44}$ there was general approval. This case is significant both in the field of negligence and in the field of fraud. The defendants, a firm of public accountants, had been employed to prepare and certify a balance sheet for a company. To finance its operation, this company required extensive credit and borrowed large sums of money

42 Courteen Seed Co. v. Hong Kong and S. B. Corp., 245 N. Y. 377, I57 N. E. 272 (I927).

43 Doyle v. Chatham \& Phoenix Nat. Bank, 253 N. Y. 369 , 171 N. E. 574 (1930).

4229 App. Div. 58I, 243 N. Y. Supp. I79 (Ist Dep't 1930), rev'd, 255 N. Y. I70, I74 N. E. 44 r (193I).

398 HARV.

4I6 YALE

COL. 46 
from banks and money lenders. All this was known to the defendants, who also knew that in the usual course of business the balance sheet, when certified, would be exhibited to banks, creditors, stockholders, purchasers and sellers, according to the needs of the occasion, as the basis of financial dealings. To satisfy this purpose, the defendants supplied thirty-two copies as counterpart originals. The defendants did not know the persons to whom these would be shown or the extent or number of the transactions in which they were used; nor did they know of the existence of the plaintiff who previously had dealt, in a small way, with the company. In reliance upon the certificate furnished by the defendants and, it may be presumed, in view of the general reputation of the company, the plaintiff advanced to it some $\$ 165,000$. About nine months thereafter, the company became insolvent. It then appeared that the statement made by the defendants had erroneously included as an asset a nonexistent item of some $\$ 900,000$, the lack of which caused the company to be insolvent. Had the facts been correctly certified by the defendants, the plaintiff would not have made the loan.

The Appellate Division had found negligence but no fraud and imposed liability upon the basis of the elements which in previous cases had appeared to be important, that is, the knowledge that the certificate would be shown to third persons who would rely upon it, the reliance by the plaintiff in the precise way foreseen, and the loss resulting thereafter. Finch, in dissenting, found that the certificate was in such form that the plaintiff should not have relied upon it and also that there was contributory negligence in his failure to look at the collateral. Of more importance, to his mind, were the facts that the certificate was not prepared for the use of any definite class of persons and that the sum paid the defendants for the accounting was so small in comparison with the liability which might result that it would be unfair to make the defendants responsible. The Court of Appeals found negligence with no liability, but ordered a new trial upon the issue of fraud.

The opinion of Cardozo, in dealing with the question of the defendant's liability for negligence, illustrates both his strength and his weakness. His opinion is strong in its realistic approach 
and the persuasiveness with which the human problems involved are dealt. He squarely faces the reasons for a difference in the rules of liability for conduct causing physical harm and that which results in merely pecuniary loss. He no longer relies on the distinction made in Glanzer v. Shepard between negligence in physical activity, which induces a mistake causing a misrepresentation, and negligence merely in speaking. He focuses attention upon the comparatively narrow limits within which recovery for fraud, a greater offense than negligence, had been permitted. But above all he stresses the practical effect of imposing liability. "If lithbility for negligence exists, a thoughtless slip or blunder, the failure to detect a theft or forgery beneath the cover of deceptive entries, may expose accountants to a liability in an indeterminate amount for an indeterminate time to an indeterminate class. The hazards of a business conducted on these terms are so extreme as to enkindle doubt whether a flaw may not exist in the implication of a duty that exposes to these consequences." It is this possibility of liability of unknown extent which distinguishes the Ultramares case from that where beans were misweighed or misrepresentations made as to the location of goods, since there the limit of liability was the value of the chattels with reference to which the statements were made. There is a closer analogy to the stock ticker case where likewise the extent of liability, once its existence was admitted, could not be foretold. In the one type of case, a comparatively small premium will secure insurance; in the other, since the upper limit of liability is indefinite, complete protection can probably not be obtained.

But Cardozo weakened his opinion by making distinctions where there are no differences. Thus he says that in Glanzer $v$. Shepard, the service rendered was primarily for the information of a third person, whereas in the Ultramares case, the information was primarily for the benefit of the corporation and not for that of the lenders. It is reasonably obvious that the weight card in the former case was for the benefit of the seller as well as for the benefit of the buyer, and that in the latter case the duplicate originals were intended for the benefit of third persons as well as for the client. To distinguish the case between the railroad and 
the consignee, he says that there the defendant had peculiar opportunity for knowledge; certainly it was true in the Ultramares case that the effectiveness of the accountant's statement was because his business was to acquire very intimate and thorough knowledge. Both the consignee case and the case holding the trustee liable to the bondholder could have been distinguished on other grounds; but the unknowable extent of possible liability is the most rational. Otherwise, if decision is to be made on principle rather than on common-law technicalities, there should be liability in all cases or in none. It is probable that fears expressed for the solvency of the accounting profession, if liability were to be imposed, were ill-founded. Whether or not we believe that the Securities and Exchange Act is wise, it does not seem credible that the liability imposed by that act upon "every accountant, engineer or appraiser" who has been named as having prepared or certified any part of the registration statement or report or valuation used in connection with it will result in the insolvency of many honest men.

The law of negligent misrepresentation which causes only pecuniary loss, with its separation from the law of negligence generally and with its excrescence of estoppel by which there may be liability even without negligence, is confused and incoherent. The Ultramares opinion, because of the manner of dealing with previous decisions, did little to lessen the confusion. Upon this branch of the case I cannot but feel that Cardozo missed an opportunity of clarification. Had he been content to point out that the sound theory can never differ from good practice, and that practical reasons require that the liability for causing merely pecuniary loss should be more limited than the liability for causing physical harm, he would have stilled some of the critics.

But perhaps this is being too captious. The decision itself can be defended; certainly there is no way of proving the decision to be wrong in effect. The greater liability would undoubtedly entail greater expense for those obtaining certificates from reputable lawyers and accountants or, in the alternative, drive them to a financially irresponsible professional group. Moreover, it must be borne in mind that the New York court had taken the lead in 
this field and that the courts of other states had shown little inclination to follow. In the absence of convincing evidence to the contrary, it is rational to make the assumption that Cardozo showed his usual judicial sense in deciding to leave to the legislature the responsibility of carrying to a greater extent the liability for negligent misrepresentation causing only pecuniary loss.

While the Ultramares case is best known on account of its negligence problem, the holding of the court that if on a new trial it should be found that the agent of the defendant knowingly misrepresented the facts the defendant should be liable constitutes a landmark in the law of fraud.

Cardozo's belief that by even slightly enlarging the boundaries of liability for negligent misrepresentation the court would find itself going further than other courts had gone in imposing liability for intentional misrepresentation was well founded. Liability for fraud although enlarged in other directions, had never been expanded by the courts much beyond its original limitation in this respect. By 1930 , the privilege of one bargaining party to cheat another had gradually been narrowed; the field of permissible sellers' lies had been made smaller. Liability for a misrepresentation as to the speaker's state of mind, once denied in New York as well as in other states, had become established. Promises and prophecies had been recognized as containing elements of present representations. There had been created a duty to speak when silence would otherwise create an inference of fact contrary to the truth, as in the case where purchases are made with knowledge of hopeless insolvency. The field of liability for misrepresentation of opinions, including statements of law, had been enlarged. In most states it was no longer a defense that the plaintiff was a fool. But, by and large, there had been no corresponding extension of liability to third persons. It was thus possible for the Restatement of Torts to state that one who knowingly makes a misstatement to another is not liable to a third person for its repetition although the maker "knows that its recipient may probably or will to a substantial certainty repeat it to a third person for the purpose of influencing his conduct in transactions with him," ti

45 $\S 533$, comment $b$.

402 HARV.

420 YALE

cot. 50 
and that, with narrow exceptions, one who makes a fraudulent misrepresentation is liable "only to those persons to whom it is made with the intent to cause them to act in reliance upon it and to such persons only for the pecuniary harm suffered by them by relying upon it in the transaction or type of transaction in which the maker intended to influence their conduct." 18 I believe that this represents the vanishing viewpoint of generations of judges who looked upon actions of fraud with a suspicion engendered perhaps by the prevalence in business of the ethics of the horse trader or perhaps because of the ease with which the plaintiff could manufacture evidence. But that such viewpoint still has vitality cannot be doubted.

It is because of this background that the decision of the court to allow recovery of damages by a stranger to the transaction whose personality was unknown to the defendant and in whose deception the defendant had no interest is of great importance. This is especially true in view of the broad characterization of fraud as including a situation where the specific fraud, as existing evidence would indicate, involved little more than negligence. The effect of holding that the jury might infer fraud from the fact that the certificate had been given without more investigation than that made by the defendant, on the ground that it constituted a statement of the existence of facts as to which the certifier knew that he had no knowledge, ${ }^{4 \pi}$ is largely to diminish, in practice, the

$46 \$ 53 \mathrm{I}$. The statement in this section is, however, broader than that in some of the earlier decisions which, in words at least, confined liability to those persons to whom the misrepresentation was made for the purpose of deceiving them. If there is a remnant of this view, the Ultramares case should end it.

47 See State Street Trust Co. v. Ernst, 278 N. Y. 104, 15 N. E.(2d) 416 (1938), where in reversing a judgment directed for an accountant by the Appellate Division, Finch, J., says: "Accountants, however, may be liable to third parties, even where there is lacking deliberate or active fraud. A representation certified as true to the knowledge of the accountants when knowledge there is none, a reckless misstatement, or an opinion based on grounds so flimsy as to lead to the conclusion that there was no genuine belief in its truth, are all sufficient upon which to base liability. A refusal to see the obvious, a failure to investigate the doubtiul, if suficiently gross, may furnish evidence leading to an inference of fraud so as to impose liability for losses suffered by those who rely on the balance sheet. In other words, heedlessness and reckless disregard of consequence may take the place of deliberate intention." It is noteworthy that Finch who as a member of the Appellate Division had dissented from the judgment of that court for the plaintiff in the Ultramares 
distinction between fraud and negligence. If the defendant has been guilty of seriously wrongful conduct, we can trust to the jury to take care of the equities in the situation.

That a fraudulent person should be protected from liability to third persons who had reason to rely upon the statements seems defensible only from a purely historical standpoint. The hardships which may attend the imposition of liability for merely negligent statements do not exist where the statement is knowingly false. It is true that liability will in many cases be imposed upon an innocent principal, as in the Ultramares case, but the likelihood of a fraudulent or bribable agent is far less than that of a negligent or overcredulous agent. The restriction of liability in such cases far beyond the liability for negligent conduct causing physical harm is anomalous. The Ultramares opinion extended liability for fraud to permit suit by persons whose identity was unknown to the defendant and whom it was not the primary purpose of the defendant to defraud. From this point it is but a short step to permit recovery by persons of a class which the defendant should have realized would rely upon his misrepresentation whether or not he had persons of that sort in mind. It is here that " the assault upon the citadel of privity" should be most vigorous. The cheat has no barrier of sympathy behind which he can take refuge when once a breach in the citadel is made.

Warren A. Seavey. ${ }^{48}$

Harvard LaW School.

case, wrote the opinion, while two members of the court dissented on the ground that they could find no evidence of wrongdoing other than that resulting from an honest error of judgment. The curtains which failed to exclude the nose of tha camel are now further parted to admit the head.

$48 \mathrm{My}$ colleague, Mr. Thurston, who looked over the manuscript to discern heresies, permits me to say that the views here stated are in substance those which he and I have developed and shared in our work together. 


\section{OTHER SIGNIFICANT OPINIONS}

The six cases reviewed above are, I believe, representative of Cardozo's opinions in tort cases. Below are thumbnail sketches of a few of the more than one hundred opinions in tort cases which illustrate his permeating influence and his wisdom in decision.

\section{Negligeruce}

Perry v. Rochester Lime Co., 219 N. Y. 60, II3 N. E. 529 (rgr6). Forecasting the Palsgraf case, liability was imposed upon a person who had stored nitroglycerin caps where a child found them. The defendant was made " answerable for those consequences that ought to have been foreseen by a reasonably prudent man."

Adams v. Bullock, 227 N. Y. 208, r25 N. E. 93 (19rg). The plaintiff, a boy of twelve, swung a wire from a bridge which he was crossing, causing it to come into contact with the defendant's trolley wire a fev feet below the parapet of the bridge. In reversing a judgment for the plaintiff, Cardozo makes plain that the factors entering into the conception of negligence are risk on the one hand, utility and expense on the other. "Chance of harm, though remote, may betoken negligence, if needless. Facility of protection may impose a duty to protect. With trolley wires, the case is different. Insulation is impossible. Guards here and there are of little value. To avert the possibility of this accident and others like it at one point or another on the route, the defendant must have abandoned the overhead system and put the wire underground. Neither its power nor its duty to make the change is shown."

Martin v. Herzog, 228 N. Y. 164,126 N. E. SI4 (r920). In this case is a superb discussion of the effect of the disobedience of statutes requiring vehicles to have lights when driven on the road, apropos of the discussion whether the violation of a statute has of itself the same effect as negligence. Where the failure to obey the statute is a cause of the accident "jurors have no dispensing power by which they may relax the duty that one traveler on the highway has under the statute to another. It is error to tell them that they have. The omission of these lights was a wrong and being wholly unexcused was also a negligent wrong." Further, "evidence of a collision occurring more than an hour after sundown between a car and an unseen buggy, proceeding without lights, is evidence from which a causal connection may be inferred between the collision and the lack of signals. . . . There may indeed be times when the lights on the highway are so many and so bright that a light on the wagon is superfluous. If that is so, it is for the ofiender to go forward with the evidence, and prove that the illumination was $a$ kind of substitute performance."

Hynes v. New York C. R. R., 23I N. Y. 229, I3I N. E. SgS (I92I). A sixteen-year old boy swam from the west bank of the Harlem River to the east bank where he climbed upon a springboard which had been fastened to a bulkhead on the defendant's land and which projected from its property over the water. The boy had climbed on the bulkhead and proceeded to the end 
of the springboard over the water when he was struck by wires which fell from one of the defendant's poles. In a colorful opinion, Cardozo declined to apply the severe common-law rule protecting landowners from liability to trespassers harmed by static conditions of the land, even though the plank on which the boy was when struck was a fixture in the defendant's possession. "Jumping from a boat or a barrel, the boy would have been a bather in the river. Jumping from the end of a springboard, he was no longer, it is said. a bather, but a trespasser on a right of way. Rights and duties in systems of living law are not built upon such quicksands."

Schloendorff v. New York Hospital, 2II N. Y. I25, 105 N. E. 92 (1914); Hamburger v. Cornell University, 240 N. Y. 328,148 N. E. 539 (1925). In these two cases, in the first of which recovery was denied against a hospital and in the second, against a university, Cardozo delineates the extent of immunity of eleemosynary institutions and the reasons for granting it.

McFarlane v. City of Niagara Falls, 247 N. Y. 340,160 N. E. 391 (1928). This was an action brought by a woman who stumbled on a slight projection on the sidewalk, which she had previously noticed. The plaintiff claimed that the projection constituted a nuisance and that contributory negligence was not a defense. In reversing the judgment for the plaintifi, the amorphous nature of nuisance is completely exposed, as is likewise the fallacy of the oftrepeated statement that contributory negligence is not a defense in an action for nuisance. Cardozo points out that wherever the substantial wrong in a condition alleged to be a nuisance is negligence, the defense of contributory negligence is as pertinent as in any other negligence case. It is difficult to see how, after this opinion, courts can continue to state, as applicable to all forms of nuisance, that contributory negligence is not a defense.

Woloszynowski v. New York C. R. R., 254 N. Y. 206, I72 N. E. 47I (1930). In reversing a judgment for the plaintiff, Cardozo reiterates the New York rule that the last clear chance doctrine does not apply unless the defendant fails to use reasonable efforts to avert the harm after knowledge of the danger. He takes account of the short time for averting the harm and allows leeway after discovery of the facts for an error of judgment. "In the light of the wisdom that follows the event, we can see that the outcome might have been better if they had done something less. That is not enough."

Cullings v. Goetz, 256 N. Y. 287,176 N. E. 397 (1931). The defendant lessor contracted to keep the premises in repair. He failed to do so and as a result the plaintiff, a licensee of the lessee, was hurt. Judgment for the plaintiff was reversed in spite of what we may assume to be a strong desire by the court to make the defendant liable in accordance with considerable authority in the United States and with the statement in the Restatement of Torts, but contrary to the pre-existing New York rule that the landlord is not liable under these circumstances. In expressing his belief in the vitality of the doctrine of stare decisis, Cardozo states: "The doctrine, wise or unwise in its origin, has worked itself by common acquiescence into the tissues of our law. It is too deeply imbedded to be superseded or ignored. Hardly a day goes by in our great centers of population but it is applied by judges and juries in cases great and small. Countless tenants, suing for personal injuries and proving nothing more than a breach of agreement, have been dismissed without a remedy in adherence to authority."

406 HARV.

424 YALE

COL. 54 


\section{CARDOZO AND THE LAIV OF TORTS}

De Haen v. Rockwood Sprinkler Co., 258 N. Y. 350, 179 N. E. 764 (r932). In violation of statute, the general contractor for the construction of a building left a hoistway unguarded. The servants of a subcontractor placed a radiator close to a shaft and the servants of another subcontractor negligently knocked the radiator into the shaft, killing a person below. An opinion of interest because of the manner in which it is pointed out that there is liability only if the harm was within the hazard against which the statute was enacted and that while obviously the chief purpose of the statute was to protect workmen from falling, it may also have been intended to protect them from falling objects. "A safeguard has been commanded but without distinct enumeration of the hazards to be avoided. In the revealing light of experience the hazards to be avoided are disclosed to us as the hazards that ensued."

Pokora v. Wabash Ry., 292 U. S. 9S (1934). This case involved a crossing accident where the plaintiff had failed to get out of his vehicle as was necessary to gain a view of a possible approaching train. Cardozo gently but firmly explodes the idea that most of us received from reading Baltimore \& Ohio Ry. v. Goodman [275 U. S. 66 (I927)], that Mr. Justice Holmes meant to state an unyielding rule barring from recovery one who failed to stop and leave his vehicle to look, if otherwise the track could not be properly observed.

\section{Fraud}

As indicated by the Ultramares decision, Cardozo had no inhibitions against imposing liability upon those who had misrepresented or had approached the limits of proper conduct as fiduciaries, the liability frequently being imposed by the creation of a constructive trust.

Beatty v. Guggenheim, 225 N. Y. 380 , I22 N. E. 378 (1grg). The opinion is a notable expression of the rule that the court will not permit an agent to profit by taking advantage of information acquired in the course of his agency or arising out of it.

Meinhard v. Salmon, 249 N. Y. 458,164 N. E. 545 (I928). This opinion clarifies the principle of the Beatty case and sets up a high standard of conduct for one engaged in a joint enterprise with another by imposing a constructive trust in favor of the other upon a large amount of property, of which only a portion was acquired because of the relation.

Junius Construction Co. v. Cohen, 257 N. Y. 393, I78 N. E. 672 (I93I). Cardozo makes it plain that one cannot properly reveal two comparatively harmless incumbrances in order to conceal the existence of a very damageable one. One is guilty of concealment if, having undertaken or professed to mention incumbrances, he stops half way, listing only those which are unimportant and keeping silent as to the others.

McCandless, Rec'rv. Furlaud, 296 U.S. r40 (r935). A far-reaching opinion, given for the majority of a divided court, extending the liability of corporate promoters. By the expedient of owning all the shares at the time of their transfer of grossly overvalued property that was insuficient in value to satisfy the bonds issued by the company, the promoters vainly sought to escape liability to the receiver for the overvaluation. "No consent of shareholders could make such conduct lawful when challenged by the receiver as the representative of creditors." 